University of Wollongong

Research Online

Faculty of Engineering and Information

Faculty of Engineering and Information

Sciences - Papers: Part A

Sciences

$1-1-2013$

The effect of chemical composition on microstructure and properties of intercritically reheated coarse-grained heat-affected zone in X70 steels

Zhixiong Zhu

University of Wollongong, zz056@uowmail.edu.au

Lenka Kuzmikova

University of Wollongong, lenka@uow.edu.au

Huijun Li

University of Wollongong, huijun@uow.edu.au

Frank J. Barbaro

University of Wollongong, fbarbaro@uow.edu.au

Follow this and additional works at: https://ro.uow.edu.au/eispapers

Part of the Engineering Commons, and the Science and Technology Studies Commons

Research Online is the open access institutional repository for the University of Wollongong. For further information contact the UOW Library: research-pubs@uow.edu.au 


\title{
The effect of chemical composition on microstructure and properties of intercritically reheated coarse-grained heat-affected zone in X70 steels
}

\author{
Abstract \\ The current study investigates the effect of different levels of $\mathrm{Ti}, \mathrm{N}$, and $\mathrm{Ti} / \mathrm{N}$ ratios on microstructure and \\ properties in the intercritically reheated coarse-grained heat-affected zone (ICCGHAZ) of two-pass \\ submerged arc welds in API $5 \mathrm{~L}$ grade X70 pipe. Gleeble simulation was employed to reproduce the \\ ICCGHAZ of actual welds. Hardness and Charpy V-notch (CVN) tests were performed on the simulated \\ samples. The microstructure of simulated ICCGHAZ was characterized by optical microscopy and \\ scanning electron microscopy (SEM). LePera color etching technique was employed to identify and \\ quantify the martensitic-austenitic (M-A) constituent. Results show that the simulated ICCGHAZ exhibited \\ extremely low toughness, but in the studied range of $\mathrm{Ti}$ and $\mathrm{N}$, there was no correlation with $\mathrm{Ti} / \mathrm{N}$ ratio. \\ The beneficial effect of near-stoichiometric Ti/N ratio observed in coarse-grained heat-affected zone \\ (CGHAZ) did not translate to ICCGHAZ. This was because of the negative effect of the blocky M-A \\ constituent formed on prior austenite grain boundaries.
}

\section{Keywords}

composition, chemical, effect, zone, affected, heat, grained, coarse, reheated, intercritically, properties, steels, microstructure, $x 70$

\section{Disciplines \\ Engineering | Science and Technology Studies}

\section{Publication Details}

Zhu, Z., Kuzmikova, L., Li, H. \& Barbaro, F. J. (2013). The Effect of Chemical Composition on Microstructure and Properties of Intercritically Reheated Coarse-Grained Heat-Affected Zone in X70 Steels. Metallurgical and Materials Transactions B: Process Metallurgy and Materials Processing Science, 45 (1), 229-235. 


\title{
The Effect of Chemical Composition on Microstructure and Properties of Intercritically Reheated Coarse-Grained Heat-Affected Zone in X70 Steels
}

\author{
ZHIXIONG ZHU, LENKA KUZMIKOVA, HUIJUN LI, and FRANK BARBARO \\ The current study investigates the effect of different levels of $\mathrm{Ti}, \mathrm{N}$, and $\mathrm{Ti} / \mathrm{N}$ ratios on \\ microstructure and properties in the intercritically reheated coarse-grained heat-affected zone \\ (ICCGHAZ) of two-pass submerged arc welds in API 5L grade X70 pipe. Gleeble simulation \\ was employed to reproduce the ICCGHAZ of actual welds. Hardness and Charpy V-notch \\ $(\mathrm{CVN})$ tests were performed on the simulated samples. The microstructure of simulated \\ ICCGHAZ was characterized by optical microscopy and scanning electron microscopy (SEM). \\ LePera color etching technique was employed to identify and quantify the martensitic-austenitic \\ (M-A) constituent. Results show that the simulated ICCGHAZ exhibited extremely low \\ toughness, but in the studied range of $\mathrm{Ti}$ and $\mathrm{N}$, there was no correlation with $\mathrm{Ti} / \mathrm{N}$ ratio. The \\ beneficial effect of near-stoichiometric $\mathrm{Ti} / \mathrm{N}$ ratio observed in coarse-grained heat-affected zone \\ (CGHAZ) did not translate to ICCGHAZ. This was because of the negative effect of the blocky \\ $\mathrm{M}-\mathrm{A}$ constituent formed on prior austenite grain boundaries.
}

DOI: $10.1007 / \mathrm{s} 11663-013-0008-5$

(c) The Minerals, Metals \& Materials Society and ASM International 2013

\section{INTRODUCTION}

To meet the increased demand of energy, largediameter, high-strength pipes manufactured through twopass submerged arc welding (SAW) are widely used for the purpose of improving energy transport efficiency. Safety and reliability in operations require the use of high-quality pipelines, which minimize the detrimental effects of the extreme thermal excursions in the weld's heat-affected zone (HAZ). During welding, the desirable microstructure produced in base metal is modified by the severe thermal cycle, and the corresponding mechanical properties (especially toughness) are also significantly downgraded. Hence, the improvement of toughness in critical HAZ regions is of primary interest. ${ }^{[1-4]}$

During the two-pass SAW process, the HAZ produced by the first SAW pass is partially reheated by the subsequent outer SAW pass. The intercritically reheated coarse-grained HAZ (ICCGHAZ), is a region where coarse-grained HAZ (CGHAZ) resulting from the first pass was reheated to the intercritical temperature range (i.e., between $A_{\mathrm{c} 1}$ and $A_{\mathrm{c} 3}$ ) by the subsequent weld pass. The location of ICCGHAZ in a two-pass submerged arc welds is schematically illustrated in Figure $1^{[5]}$ It has been reported that this region exhibits the most

ZHIXIONG ZHU, Ph.D. Candidate, LENKA KUZMIKOVA, Research Fellow, and HUIJUN LI, Associate Professor, are with the School of Mechanical, Materials \& Mechatronic Engineering, University of Wollongong, Wollongong, NSW 2522, Australia. Contact e-mail: zhixiongzhu@gmail.com; zz056@uow.edu.au FRANK BARBARO, Professor, is with the School of Mechanical, Materials \& Mechatronic Engineering, University of Wollongong, and also with the CBMM Technology Suisse, 14, Rue du Rhone, Geneva 1204, Switzerland.

Manuscript submitted August 15, 2013. deteriorated toughness of all the HAZ subzones. ${ }^{[5,6]}$ The use of the crack tip opening displacement (CTOD) test, which is sensitive to fracture initiation, can reveal local brittle zones (LBZ), and so commonly reveals the ICCGHAZ as a region of low fracture toughness as evidenced by the occurrence of the so-called pop-in phenomenon. ${ }^{[7]}$ This is owing to the formation of martensitic-austenitic (M-A) islands in the partially transformed carbon-enriched regions of the CGHAZ. ${ }^{[8,9]}$ This is also supported by Silwal et al.'s findings ${ }^{[10]}$ : the toughness was decreased in CGHAZ when subjected to postweld heat treatment (PWHT) at temperature greater than $A_{\mathrm{cl}}$ temperature because of the formation of fresh martensite.

Improved HAZ toughness is a priority in the design of modern pipelines, ${ }^{[11]}$ and the addition of microalloying elements has been proposed. Small additions of Ti are widely used to control the CGHAZ austenite grain size and thus minimize the degradation in toughness associated with the thermal effects of the welding process. ${ }^{[12-15]}$ Despite the ongoing debate regarding optimum $\mathrm{Ti}, \mathrm{N}$, and $\mathrm{Ti} / \mathrm{N}$ ratio requirement, ${ }^{[16-18]}$ a previous study by the Energy Pipelines $\mathrm{CRC}$ has shown that a near-stoichiometric $\mathrm{Ti} / \mathrm{N}$ ratio exhibited slightly higher impact energy values in CGHAZ than hypo- and hyper-stoichiometric ratios primarily because of retention of a finer austenite grain size. ${ }^{[19]}$ However, the effect of Ti addition on ICCGHAZ microstructure and mechanical properties is not clear.

Many studies showed that the ICCGHAZ formed in multipass welding does exhibit deteriorated toughness, even lower than in the CGHAZ. ${ }^{[5,6,20]}$ It has been demonstrated that even subtle differences in steel composition can markedly improve toughness in ICCGHAZ. ${ }^{[21,22]}$ Therefore, to maintain adequate weld zone mechanical properties, whether an optimum $\mathrm{Ti} / \mathrm{N}$ ratio 
exists with respect to, and whether the addition of $\mathrm{Ti}$ exerts a positive effect on the microstructure and mechanical properties in the ICCGHAZ need to be well understood. In the current study, the X70 steels with almost identical composition varying only in levels of $\mathrm{Ti}$, $\mathrm{N}$, and $\mathrm{Ti} / \mathrm{N}$ ratio were used to investigate the correlation between the alloy composition and the microstructure and mechanical properties of ICCGHAZ.

\section{EXPERIMENTAL PROCEDURES}

The investigation employed three API 5L X70 UOE (i.e., U-ing, O-ing, and Expansion, pipe manufacturing process) pipes with dimension of diameter $1067 \mathrm{~mm}$ and wall thickness $14.1 \mathrm{~mm}$. The base metal chemical composition of the three studied pipeline steels is shown in Table I. It should be noted that these steels deliberately contain different $\mathrm{Ti}, \mathrm{N}$ additions, and $\mathrm{Ti} / \mathrm{N}$ ratios; however, levels of other elements as well as welding parameters are almost identical. The welding parameters of longitudinal two-pass SAW process are listed in Table II. The weld metal compositions for both passes are presented in Table III.

As the ICCGHAZ of real weld represents a very small portion of the welded joint, it would be difficult to carry out the microstructural examination and virtually impossible to prepare the samples for further mechanical testing without encountering interference from the adjacent sub-zones. To overcome this limitation, Gleeble thermal simulation technique was utilized to reproduce large volume of materials which experienced the same thermal cycle as in the specific HAZ regions of the actual welds. The square bar samples with dimension of $10 \times 10 \times 80 \mathrm{~mm}$ machined from the pipe bodies along the transverse direction were placed in a vacuum

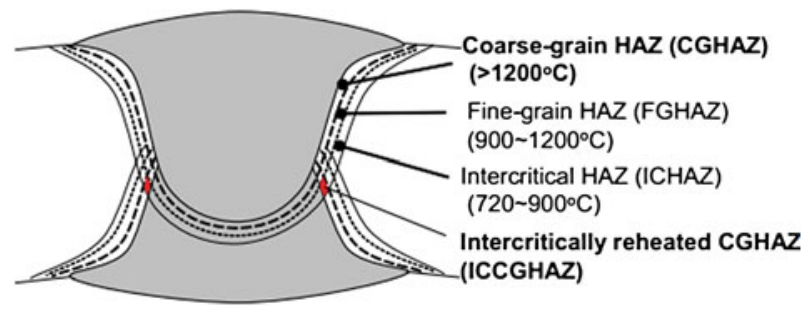

Fig. 1-Schematic illustration of ICCGHAZ in the pipe two-pass SAW seam welds. ${ }^{[5]}$ chamber and clamped with free length of $15 \mathrm{~mm}$. To accurately measure the temperature of simulated HAZ, $\mathrm{K}$-type thermocouples were spot-welded at the middle location of the samples during the simulation process. In the current study, the thermal profile of ICCGHAZ simulation is shown in Figure 2. The thermal cycles were designed using the Rakylin-2D model to produce microstructure identical with the real welds. During the first thermal cycle, to produce the CGHAZ, the specimens were heated to a peak temperature of $1623 \mathrm{~K}$ $\left(1350{ }^{\circ} \mathrm{C}\right)$ at a rate of $200 \mathrm{~K} / \mathrm{s}\left(200{ }^{\circ} \mathrm{C} / \mathrm{s}\right)$, followed by cooling to $423 \mathrm{~K}\left(150{ }^{\circ} \mathrm{C}\right)$. The cooling time from $1073 \mathrm{~K}\left(800{ }^{\circ} \mathrm{C}\right)$ to $773 \mathrm{~K}\left(500{ }^{\circ} \mathrm{C}\right)$ (i.e., $\left.\Delta t_{8 / 5}\right)$ of 38.5 seconds was based on actual mill welding parameters (Table II) to accurately duplicate the real CGHAZ of the weld. The holding time at peak temperature for both cycles was 0.5 second. The second thermal cycle utilized the same heating and cooling conditions, but to ensure accurate simulation of the subsequent, intercritical thermal cycle, the $A_{\mathrm{c} 1}$ [approximately $1073 \mathrm{~K}\left(800{ }^{\circ} \mathrm{C}\right)$ ] and $A_{\mathrm{c} 3}$ [approximately $1163 \mathrm{~K}\left(890^{\circ} \mathrm{C}\right)$ ] temperatures were determined by dilatometry techniques. The results showed this range to be approximately from $1073 \mathrm{~K}$ to $1163 \mathrm{~K}\left(800{ }^{\circ} \mathrm{C}\right.$ to $\left.890{ }^{\circ} \mathrm{C}\right)$ and that a peak temperature at the lower end of this range, i.e., $1086 \mathrm{~K}\left(813^{\circ} \mathrm{C}\right)$, produced the microstructure that most closely resembled that of the actual ICCGHAZ in the studied two-pass SAW welds. The optical micrographs (Figure 3 ) and the hardness values (Figure 6) affirmed that the selected reheating temperature of $1086 \mathrm{~K}\left(813^{\circ} \mathrm{C}\right)$ produced an accurate simulation of the real ICCGHAZ.

The as-welded and thermally simulated samples were mounted and prepared according to standard procedures. Then, the samples were etched in 2.5 pct Nital solution (2.5 pet nitric acid in ethanol) for metallographic examination using both optical microscopy and scanning electron microscopy (SEM). To identify and quantify the $\mathrm{M}-\mathrm{A}$ constituents in ICCGHAZ, the simulated samples were re-polished and etched with LePera reagent (4 pct picric acid in ethanol mixed with 1 pct sodium metabisulfite in distilled water in 1:1 volume ratio) and then subjected to microstructural examination. Afterward, the area fraction of $\mathrm{M}-\mathrm{A}$ constituent was calculated from the obtained micrographs by means of ImageJ software. Vickers hardness measurements were also carried out on both actual and thermally simulated samples. Charpy impact tests employed full size V-notch specimen geometry and were performed at

Table I. Chemical Composition of X70 Steels, in Weight Percent

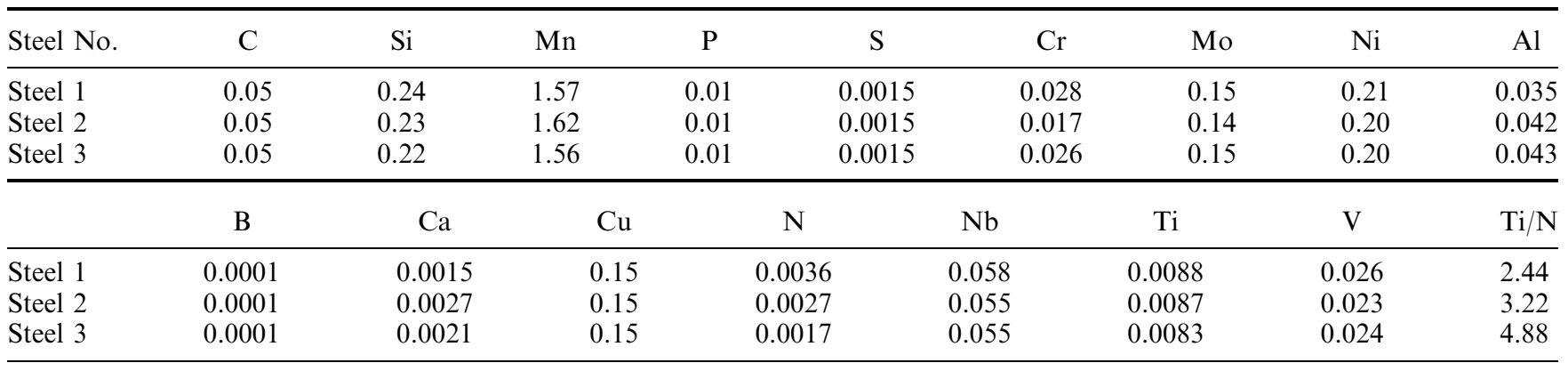


Table II. Parameters for the Two-Pass SAW Process

\begin{tabular}{|c|c|c|c|c|c|c|c|c|}
\hline \multirow[b]{2}{*}{ Welding Pass } & \multicolumn{3}{|c|}{ Current (A) } & \multicolumn{3}{|c|}{ Voltage (V) } & \multirow[b]{2}{*}{ Travel Speed $\left(\mathrm{mm} \mathrm{s}^{-1}\right)$} & \multirow[b]{2}{*}{ Heat Input $\left(\mathrm{kJ} \mathrm{mm}^{-1}\right.$} \\
\hline & $1(\mathrm{DC}+)$ & $2(\mathrm{AC})$ & $3(\mathrm{AC})$ & 1 & 2 & 3 & & \\
\hline Inside & 800 & 650 & 500 & 32 & 34 & 36 & 26.7 & 2.34 \\
\hline Outside & 900 & 600 & 500 & 34 & 38 & 40 & 28.3 & 2.46 \\
\hline
\end{tabular}

Wire classification: BHM-9; stick out: $30 \pm 2 \mathrm{~mm}$.

Table III. Average Weld Metal Composition for Both Inside and Outside Passes of the Two-Pass SAW Welds

\begin{tabular}{lcc}
\hline Elements & Outer Weld & Inner Weld \\
\hline $\mathrm{C}$ & 0.055 & 0.055 \\
$\mathrm{Mn}$ & 1.57 & 1.575 \\
$\mathrm{Mo}$ & 0.22 & 0.215 \\
$\mathrm{Nb}$ & 0.0295 & 0.031 \\
$\mathrm{Ti}$ & 0.0175 & 0.0165 \\
$\mathrm{~V}$ & 0.0165 & 0.017 \\
$\mathrm{~B}$ & 0.0011 & 0.0010 \\
\hline
\end{tabular}

Fe-0.01P-0.35Si-0.0015S-0.14Ni-0.03Cr-0.22Mo-0.11Cu-0.015Al$\mathrm{Ca}<0.0005$, in wt pet.

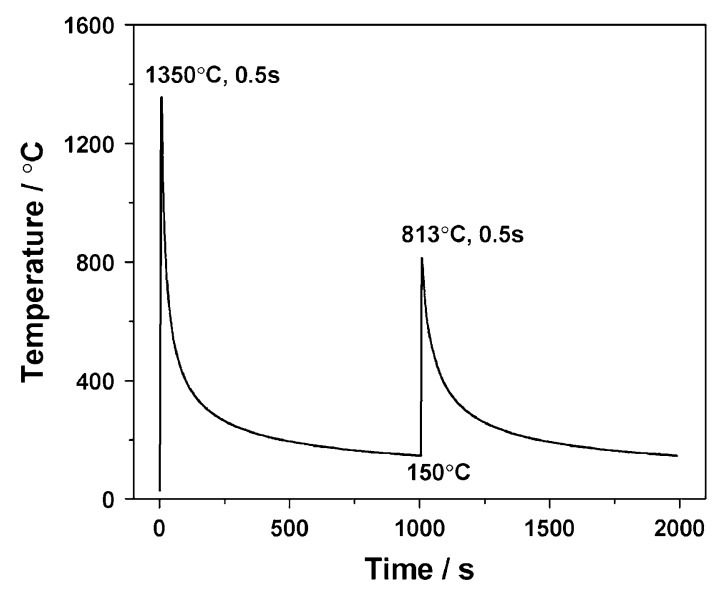

Fig. 2-Thermal profile used for the simulated ICCGHAZ.

$253 \mathrm{~K}\left(-20^{\circ} \mathrm{C}\right)$ according to ASTM E23. The notch was machined in $\mathrm{T}-\mathrm{L}$ orientation (as per ASTM E23). Hardness tests of both the real and simulated ICCGHAZ regions were conducted with a $1-\mathrm{kg}$ load on the etched sample surfaces to ensure accurate location of specific HAZ regions, and final values represent the average of three measurements.

\section{RESULTS}

The optical micrographs of the real and simulated ICCGHAZ of the three API 5L X70 steels are shown in Figure 3 . The prior austenite grain boundaries were clearly delineated by the presence of a discontinuous dark phase revealed by Nital etching, which has been identified by numerous researchers ${ }^{[23,24]}$ as $\mathrm{M}-\mathrm{A}$ constituent. The prior austenite grain boundaries were clearly evident while the general microstructure consisted of a mixture of bainitic ferrite and granular bainite.
From Figure 3, it is evident that both the real and simulated ICCGHAZ contained similar grain boundary dispersions of the $\mathrm{M}-\mathrm{A}$ constituent. It provides evidence that the simulated ICCGHAZ thermal cycle of $1086 \mathrm{~K}$ $\left(813{ }^{\circ} \mathrm{C}\right)$ closely duplicated that of the real two-pass SAW welds experienced in the production of the UOE pipe. There was no indication to suggest that the $\mathrm{Ti} / \mathrm{N}$ ratio or the austenite grain size had any influence on the size or distribution of the $\mathrm{M}-\mathrm{A}$ phase.

The microstructure of the simulated ICCGHAZ was also examined by SEM (Figure 4). It was confirmed that for all the three steels, the blocky $\mathrm{M}-\mathrm{A}$ islands were mainly formed at the prior austenite grain boundaries. It was also revealed that additional $\mathrm{M}-\mathrm{A}$ constituent with stringer morphology was dispersed intragranularly within the prior austenite grains.

Figure 5 shows the micrographs of the LePera-etched simulated ICCGHAZ, which reveal the M-A constituent as a prominent "white" phase. This technique confirmed both the coarse blocky $\mathrm{M}-\mathrm{A}$ along the prior austenite grain boundaries and the fine stringer $\mathrm{M}-\mathrm{A}$ within the prior austenite grains. Furthermore, the fraction of $\mathrm{M}-\mathrm{A}$ constituent was quantified, and the results are presented in Table IV. The average fraction of $\mathrm{M}-\mathrm{A}$ constituent was relatively consistent for all investigated steels, ranging from 6 to 7 pct. It has been demonstrated by Akselsen et al. ${ }^{[25]}$ that fraction greater than 6 pet results in serious degradation of toughness.

Figure 6 shows the Vickers hardness numbers of simulated and real ICCGHAZ compared with simulated CGHAZ. It can be seen that only marginal difference in hardness was measured for the simulated and real ICCGHAZ specimens. The average hardness values of both the simulated and real reheated zones were similar (around $240 \mathrm{HV}_{1}$ ), providing further validation of the simulation conditions employed. No significant variations in hardness were observed in the studied range of $\mathrm{Ti} / \mathrm{N}$ ratios. It should also be noted that the hardness values of both the real and simulated ICCGHAZ exhibited approximately 30 Vickers hardness points increase, compared with the simulated CGHAZ. This is thought to be associated with the presence of $\mathrm{M}-\mathrm{A}$ constituent formed along the prior austenite grain boundaries (Figures 4 and 5).

Charpy impact tests were conducted at a test temperature of $253 \mathrm{~K}\left(-20^{\circ} \mathrm{C}\right)$ to investigate the toughness properties of the simulated ICCGHAZ (Figure 7). The simulated ICCGHAZ of all studied steels exhibited extremely low Charpy impact energies, much lower than that of the simulated CGHAZ at $253 \mathrm{~K}\left(-20{ }^{\circ} \mathrm{C}\right)$. This is believed to be associated with the formation of the blocky grain boundary $\mathrm{M}-\mathrm{A}$ phase along the prior 

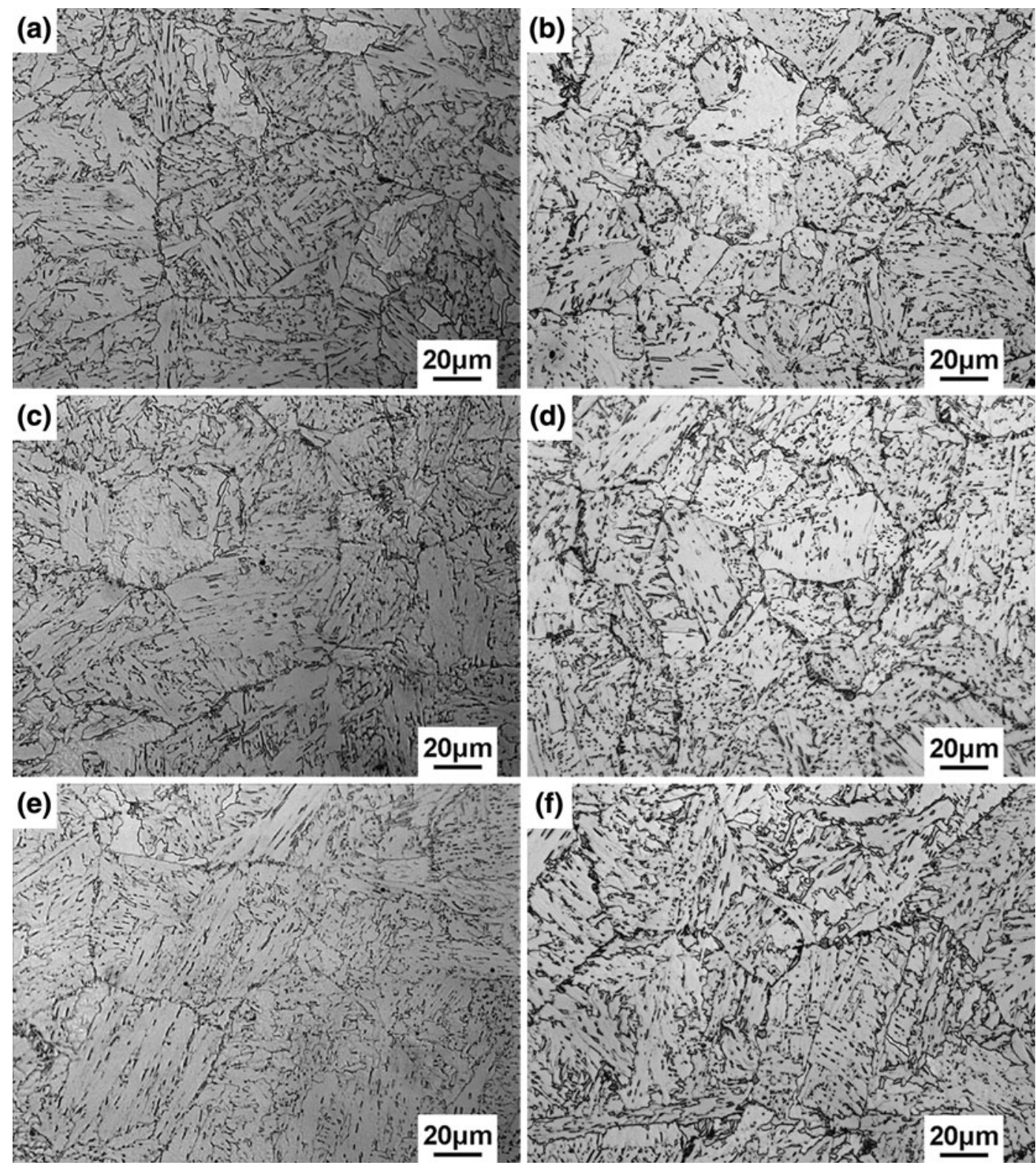

Fig. 3-Optical micrographs of real and simulated ICCGHAZ (etched in 2.5 pct Nital). (a) Steel 1, real; (b) Steel 1, simulated; (c) Steel 2, real; (d) Steel 2, simulated; (e) Steel 3, real; and $(f)$ Steel 3, simulated.

austenite grain boundaries which promotes brittle fracture initiation/propagation. ${ }^{[26]}$ It should be noted that the significant variation in toughness of simulated CGHAZ, presented in Figure 7, is related to the fact that the chosen test temperature of $253 \mathrm{~K}\left(-20^{\circ} \mathrm{C}\right)$, is very close to the transition temperature, while the ICCGHAZ is clearly on lower shelf.

\section{DISCUSSION}

It can be seen from Figures 3 and 4 that there is little influence of $\mathrm{Ti} / \mathrm{N}$ ratio on the ICCGHAZ microstructural constituents of the studied steels. This is due to the similarity of the transformation temperatures measured from the dilatometry data and thus the transformation behaviors of studied steels are identical. This is also in good agreement with the calculated transformation diagram for steels with different $\mathrm{Ti} / \mathrm{N}$ ratios presented in Reference 19.

It is well known that the distribution, fraction, and morphology of $\mathrm{M}-\mathrm{A}$ constituents play a significant role in the ICCGHAZ. ${ }^{[27]}$ In the current study, the microstructures of both the real and simulated ICCGHAZ contained two types of $\mathrm{M}-\mathrm{A}$ island morphology:

(a) blocky $\mathrm{M}-\mathrm{A}$ islands formed along the prior austenite grain boundaries, and

(b) fine stringer- or film-like $\mathrm{M}-\mathrm{A}$ islands formed intragranularly between the ferrite plates.

To simulate the ICCGHAZ of the two-pass SAW welds, the current study utilized the peak temperature of 

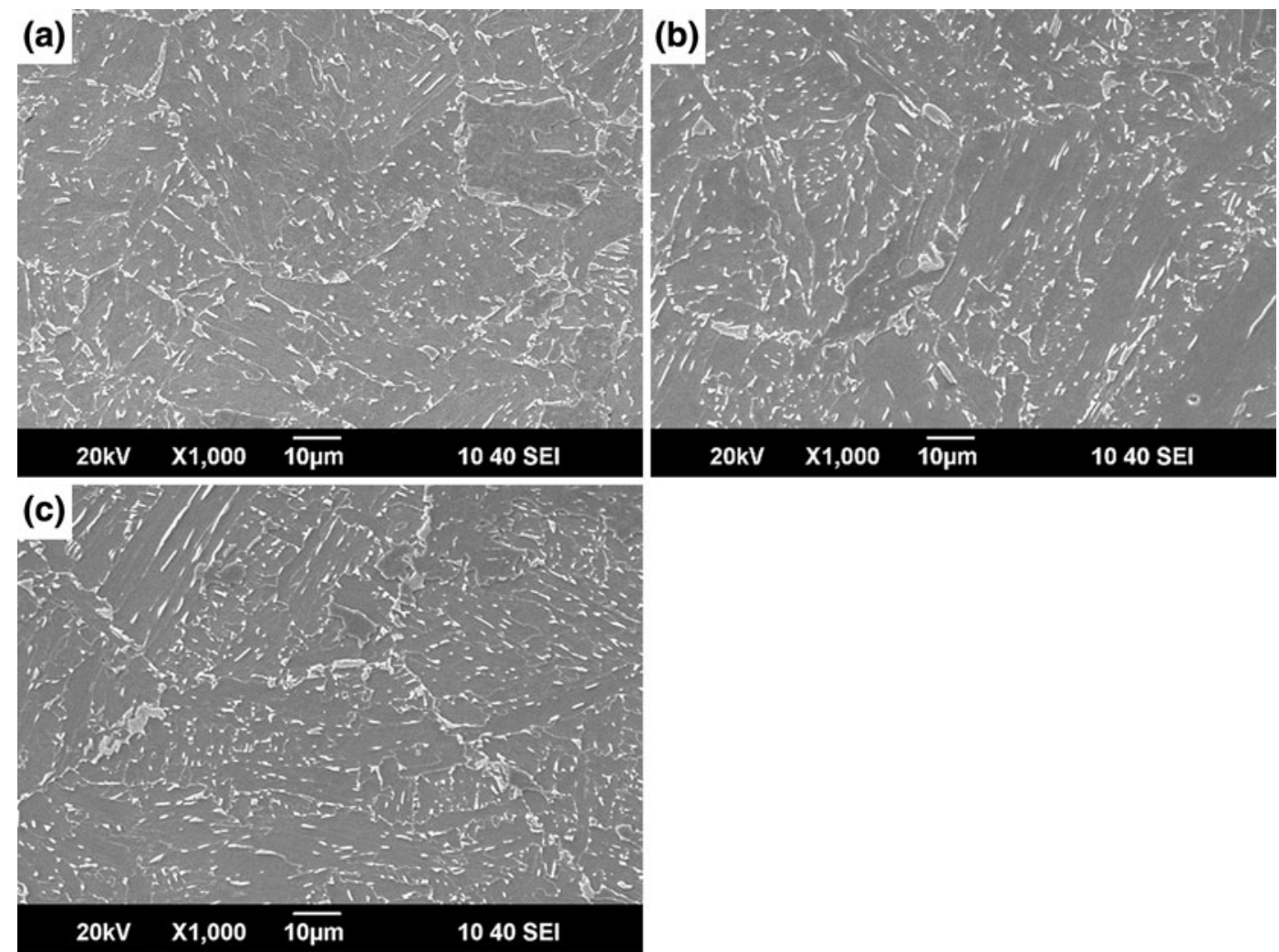

Fig. 4 -SEM micrographs of simulated ICCGHAZ (etched in 2.5 pct Nital): (a) Steel 1; (b) Steel 2; and (c) Steel 3.
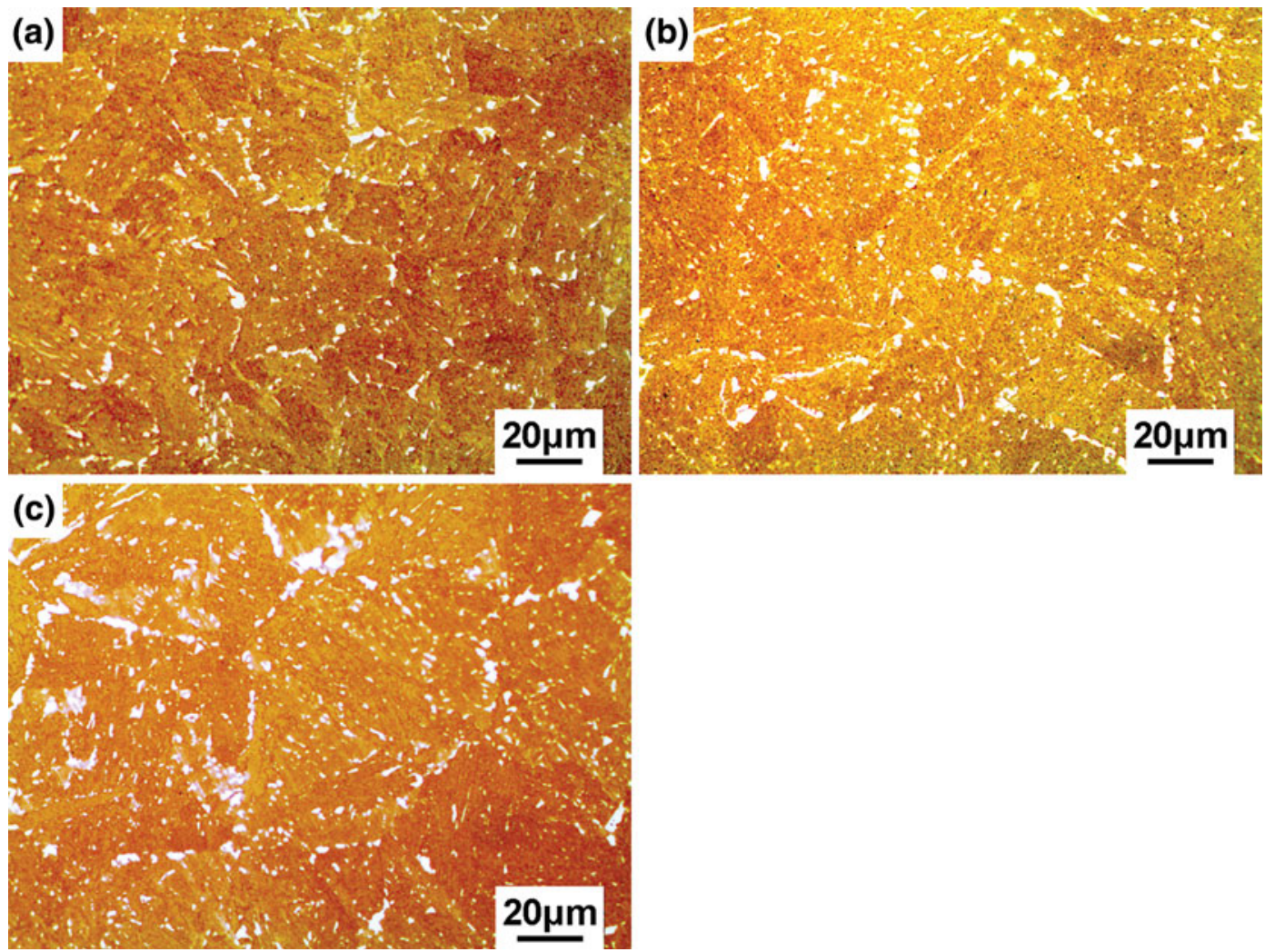

Fig. 5-The microstructure after etching in LePera reagent showing the M-A constituent in the simulated ICCGHAZ in X70 steels with different Ti/N ratios: (a) Steel 1; (b) Steel 2; and (c) Steel 3. 


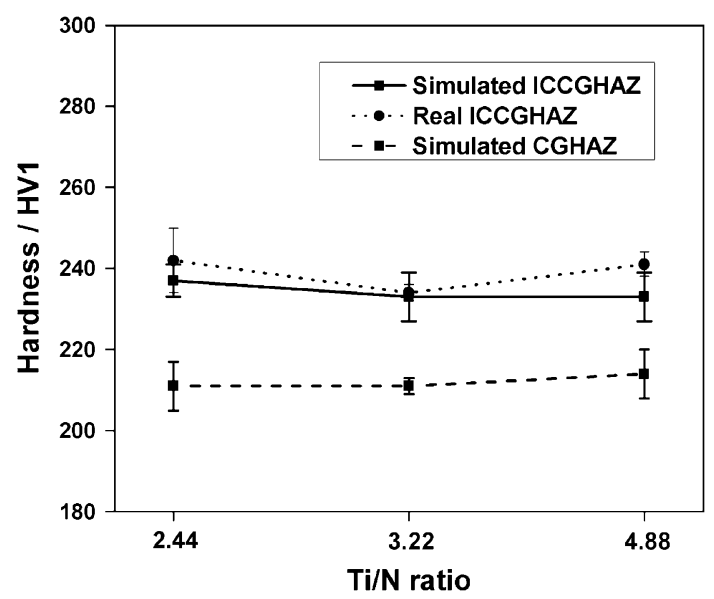

Fig. 6-Hardness (1-kg load) of real and simulated ICCGHAZ compared with simulated CGHAZ for steels having different $\mathrm{Ti} / \mathrm{N}$ ratios.

Table IV. Fraction of M-A Constituent in the Simulated ICCGHAZ as a Function of Ti/N Ratio

\begin{tabular}{lccc}
\hline Ti/N Ratio & 2.44 (Steel 1) & 3.22 (Steel 2) & 4.88 (Steel 3) \\
\hline $\begin{array}{c}\text { Fraction of } \\
\text { M-A (pct) }\end{array}$ & $7.1 \pm 0.7$ & $6.6 \pm 0.4$ & $6.2 \pm 0.4$ \\
\hline
\end{tabular}

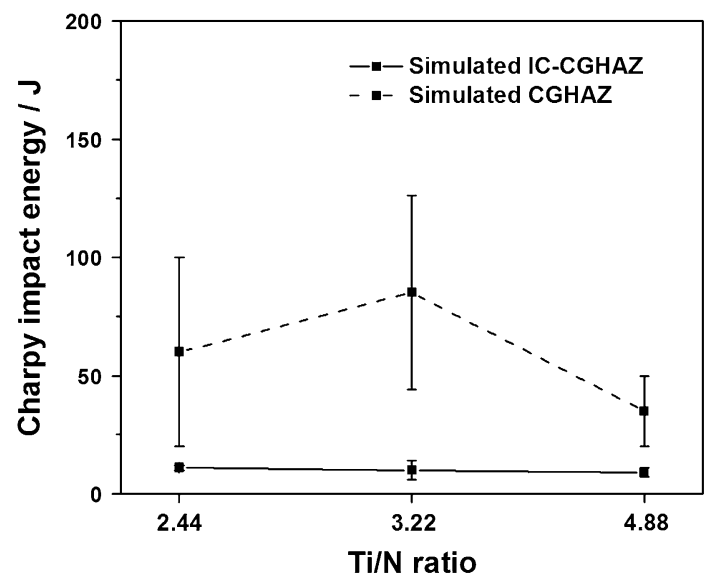

Fig. 7-Charpy impact energy of simulated ICCGHAZ and simulated CGHAZ for steels with different $\mathrm{Ti} / \mathrm{N}$ ratios [full size specimens, test temperature $\left.253 \mathrm{~K}\left(-20^{\circ} \mathrm{C}\right)\right]$.

$1086 \mathrm{~K}\left(813{ }^{\circ} \mathrm{C}\right)$ (between $A_{\mathrm{c} 1}$ and $\left.A_{\mathrm{c} 3}\right)$ for the second thermal cycle. This temperature is at the lower end of the intercritical range and so resulted in a low level of re-austenitization of the CGHAZ produced by the first thermal cycle. Exceeding the $A_{\mathrm{c} 1}$ temperature results in the formation of austenite at the grain boundaries, which provides an easy path for diffusion of carbon to accumulate in the newly formed austenite. The increased hardenability of this carbon-enriched grain boundary austenite promotes the formation of a small fraction of martensite on cooling, while some austenite is retained because the $M_{f}$ is less than the room temperature. The blocky grain boundary phase is therefore a mixture of martensite and austenite, $\mathrm{M}-\mathrm{A}$. Increased temperatures within the intercritical range result in the formation of more austenite with an overall lower hardenability, and so $\mathrm{M}-\mathrm{A}$ is unable to form at the prior austenite grain boundaries, i.e., lower carbon enrichment. ${ }^{[28]}$

The hardness of ICCGHAZ of the three steels was approximately $240 \mathrm{HV}_{1}$, which is around 30 Vickers points harder than the original CGHAZ ${ }^{[19]}$ This hardness increase is attributed to the formation of the blocky $\mathrm{M}-\mathrm{A}$ islands at the prior austenite grain boundaries. There was no influence of $\mathrm{Ti} / \mathrm{N}$ ratio on the hardness of the ICCGHAZ in either of the real or simulated heat treatments. The prime determinant of hardness was the fraction of blocky grain boundary $\mathrm{M}-\mathrm{A}$ and its compositional effect on transformation.

It has been demonstrated that control of the $\mathrm{Ti} / \mathrm{N}$ ratio around the stoichiometric ratio can provide a tighter control of austenite grain size in the as-deposited CGHAZ, which translates into an improved average fracture toughness as measured by the Charpy test. ${ }^{[19]}$ In the evaluation of these steels, where the CGHAZ has been reheated into the intercritical temperature region, where only partial austenitization occurs, it was not expected that any change would occur in the prior austenite grain size. This is because the reheating temperature is not expected to promote further austenite grain growth and the austenite grain size in ICCGHAZ is inherited from the original CGHAZ. ${ }^{[5]}$ Thus, it was anticipated that Steel 2 with a near-stoichiometric ratio may have had translated beneficial effect of finer CGHAZ grain size into improved toughness of the ICCGHAZ. Nevertheless, as demonstrated in Figure 7, the absorbed energy for steels with various $\mathrm{Ti} / \mathrm{N}$ ratios was very low and did not show any correlation with $\mathrm{Ti} / \mathrm{N}$ ratio. This is due to the presence of the blocky grain boundary $\mathrm{M}-\mathrm{A}$ constituent that appears to be the dominant factor in determination of toughness in ICCGHAZ. ${ }^{[22,29]}$ In other words, any improvement in toughness of the original CGHAZ can be overridden by the formation of grain boundary $\mathrm{M}-\mathrm{A}$ constituent. This is attributed to the blocky $\mathrm{M}-\mathrm{A}$ phase along the prior austenite grain boundaries providing fracture initiation sites as evidenced by the remnants of these particles on the fracture surfaces. ${ }^{[26]}$ The local stress and strain concentration surrounding the blocky $\mathrm{M}-\mathrm{A}$ particles along the prior austenite grain boundaries assists cleavage fracture initiation ${ }^{[26,30]}$ and also an easy path for crack propagation.

The current study demonstrates that the beneficial effects of the near-stoichiometric Ti/ $\mathrm{N}$ ratio on CGHAZ properties ${ }^{[19]}$ does not extend to the ICCGHAZ toughness, and that the formation of blocky M-A constituent along the prior austenite grain boundaries is the most detrimental factor deteriorating ICCGHAZ toughness. Elimination or minimization of blocky $\mathrm{M}-\mathrm{A}$ constituent formed at the prior austenite grain boundaries in ICCGHAZ has the potential to significantly improve ICCGHAZ toughness. As the ICCGHAZ is produced by the overlapping of weld HAZs from different weld beads, any methods which can reduce the overlap are considered to be beneficial to overcoming the problems associated with ICCGHAZ. The following two possible 
methods are proposed: (1) use the welding procedures with low heat input to reduce the area of the HAZ; and (2) modify the weld bead shape to minimize the overlap. It is important to note that the extremely low fracture toughness level recorded in these ICCGHAZ simulated specimens is directly related to the large areas of specific microstructures produced. Such large areas of these specific microstructures would not exist in the actual welded pipe, and so do not reflect the properties of the pipe.

\section{CONCLUSIONS}

The microstructure and fracture toughness of the ICCGHAZ in X70 steels with three different $\mathrm{Ti} / \mathrm{N}$ ratios were investigated and the following conclusions were drawn:

1. Optical microscopy and SEM along with special etching techniques have shown that a blocky grain boundary $\mathrm{M}-\mathrm{A}$ constituent forms along the prior austenite grain boundaries when the CGHAZ is reheated into the intercritical temperature region.

2. The reheat temperature has a dominant effect on the morphology and fraction of $\mathrm{M}-\mathrm{A}$ phase formed. A low intercritical reheat temperature of $1086 \mathrm{~K}$ $\left(813{ }^{\circ} \mathrm{C}\right)$ results in the formation of a small fraction of austenite along the prior austenite grain boundary, which is enriched in carbon and so possesses high hardenability.

3. There was no correlation between $\mathrm{Ti} / \mathrm{N}$ ratio and the fraction and morphology of the grain boundary $\mathrm{M}-\mathrm{A}$ constituent.

4. The ICCGHAZ possessed a higher hardness and lower fracture toughness than the original CGHAZ, owing to the presence of the blocky grain boundary $\mathrm{M}-\mathrm{A}$ constituent.

\section{ACKNOWLEDGEMENTS}

The current study was funded by the Energy Pipelines CRC, supported through the Australian Government's Cooperative Research Centers Program. The cash and in-kind supports from the APIA RSC are gratefully acknowledged. Special thanks are extended to Lei Zheng and Mingzhuo Bai (BaoSteel, China) for providing materials to conduct this research. One of the authors (Zhixiong Zhu) appreciates the funding support from China Scholarship Council.

\section{REFERENCES}

1. A. Liessem and M. Erdelen-Peppler: Proceedings of 5th Int. Pipeline Conf., Calgary, Canada, 2004, pp. 1871-78.

2. X. Zhang and H. Gao: Trans. Jpn. Weld. Res. Inst., 2012, vol. 2011, pp. 101-04.

3. F. Minami, Y. Nakano, S. Suzuki, T. Shiwawu, Y. Moriya, Y. Hagiwara, and M. Toyoda: Weld. Int., 1995, vol. 9, pp. 546-53.

4. V. Gliha, T. Vuherer, B. Ule, and J. Vojvodic-Tuma: Sci. Technol. Weld. Join., 2004, vol. 9, pp. 399-406.

5. N. Ishikawa, T. Shinmiya, S. Igi, and J. Kondo: Proceedings of 6th Int. Pipeline Conf., Calgary, Canada, 2006, pp. 223-30.

6. C. Zhuang, N. Li, S. Wang, W. Lin, and J. Ren: ASME 2009 Pressure Vessels and Piping Conf., Prague, Czech Republic, 2009, pp. 1311-19.

7. H. Raji and H. Pisarski: Private Report, TWI, UK, 2012, pp. $1-19$.

8. H.I. McHenry and J.M. Potter: Fatigue and Fracture Testing of Weldments, ASTM International, Philadelphia, 1990, pp. 204-228.

9. T. Haze: Metallurgical Factors Controlling HAZ Toughness in HT50 Steels, International Institute of Welding, Tokyo, 1986, pp. 1423-86.

10. B. Silwal, L. Li, A. Deceuster, and B. Griffiths: Weld. Res., 2013, vol. 92 , pp. $80 \mathrm{~s}-87 \mathrm{~s}$.

11. J.B. Ju, J.S. Lee, and J. Jang: Mater. Lett., 2007, vol. 61, pp. 517880.

12. F. Pickering: Proceedings of 35th Mechanical Working and Steel Processing Conf., Pittsburgh, 1993, pp. 477-91.

13. K. He and T. Baker: Mater. Sci. Eng., A, 1993, vol. 169, pp. 53-65.

14. T. Gladman and D. Dulieu: Met. Sci., 1974, vol. 8, pp. 167-76.

15. L.E. Svensson: Control of Microstructure and Properties in Steel Arc Welds, CRC Press, Florida, 1994, pp. 1-256.

16. S. Mukae, K. Nishio, and M. Katoh: Trans. Jpn Weld. Soc., 1987, vol. 18 , pp. $148-58$

17. M. Okatsu, K. Oi, K. Ihara, and T. Hoshino: Proceedings of $23 r d$ Int. Conf. on Offshore Mechanics and Arctic Engineering, Vancouver, Canada, pp. 751-56.

18. C. Penniston, L. Collins, and F. Hamad: Proceedings of 7th Int. Pipeline Conf., Calgary, Canada, 2008, pp. 75-83.

19. Z. Zhu, M. Marimuthu, L. Kuzmikova, H. Li, F. Barbaro, L. Zheng, M. Bai, and C. Jones: Sci. Technol. Weld. Join., 2013, vol. 18 , pp. 45-51.

20. J.B. Ju, W.S. Kim, and J. Jang: Mater. Sci. Eng. A, 2012, vol. 546, pp. 258-62.

21. C. Thaulow, A. Gunleiksrud, A. Paauw, and O. Naess: Met. Constr., 1985, vol. 17, pp. 94R-99R.

22. B. Kim, S. Lee, N. Kim, and D. Lee: Metall. Trans. A, 1991, vol. 22 A, pp. 139-49.

23. F.J. Barbaro and R.H. Edwards: Report No. PK/TSM/87/013, BHP Steel International Group, NSW, Australia, March 1987, pp. 1-8.

24. S. Moeinifar, A.H. Kokabi, and H.R.M. Hosseini: Mater. Des., 2010, vol. 31, pp. 2948-2955.

25. O. Akselsen, J. Solberg, and Ø. Grong: Scand. J. Metall., 1988, vol. 17, pp. 194-200.

26. J. King: Metall. Mater. Trans. A, 1994, vol. 25A, pp. 563-73.

27. R.O. Laitinen: Improvement of Weld HAZ Toughness at Low Heat Input by Controlling the Distribution of $M-A$ Constituents, University of Oulu, Finland, 2006, pp. 48-82.

28. H. Bhadeshia: Proceedings of Int. Seminar on Welding of High Strength Pipeline Steels, Araxá, Brazil, 2011, paper no. 5, pp. 1-9.

29. Y. Li, D. Crowther, M. Green, P. Mitchell, and T. Baker: ISIJ Int., 2001, vol. 41, pp. 46-55.

30. S. Moeinifar, A.H. Kokabi, and H.R.M. Hosseini: Mater. Des., 2011, vol. 32, pp. 869-76. 